\title{
Philosophiques
}

\section{Illustration : Joanna Jones, Malerei von Ort}

Volume 23, numéro 1, printemps 1996

Critères esthétiques et métamorphoses du beau

URI : https://id.erudit.org/iderudit/027372ar

DOI : https://doi.org/10.7202/027372ar

Aller au sommaire du numéro

Éditeur(s)

Société de philosophie du Québec

ISSN

0316-2923 (imprimé)

1492-1391 (numérique)

Découvrir la revue

Citer ce document

(1996). Illustration : Joanna Jones, Malerei von Ort. Philosophiques, 23(1),

131-131. https://doi.org/10.7202/027372ar d'utilisation que vous pouvez consulter en ligne.

https://apropos.erudit.org/fr/usagers/politique-dutilisation/ 


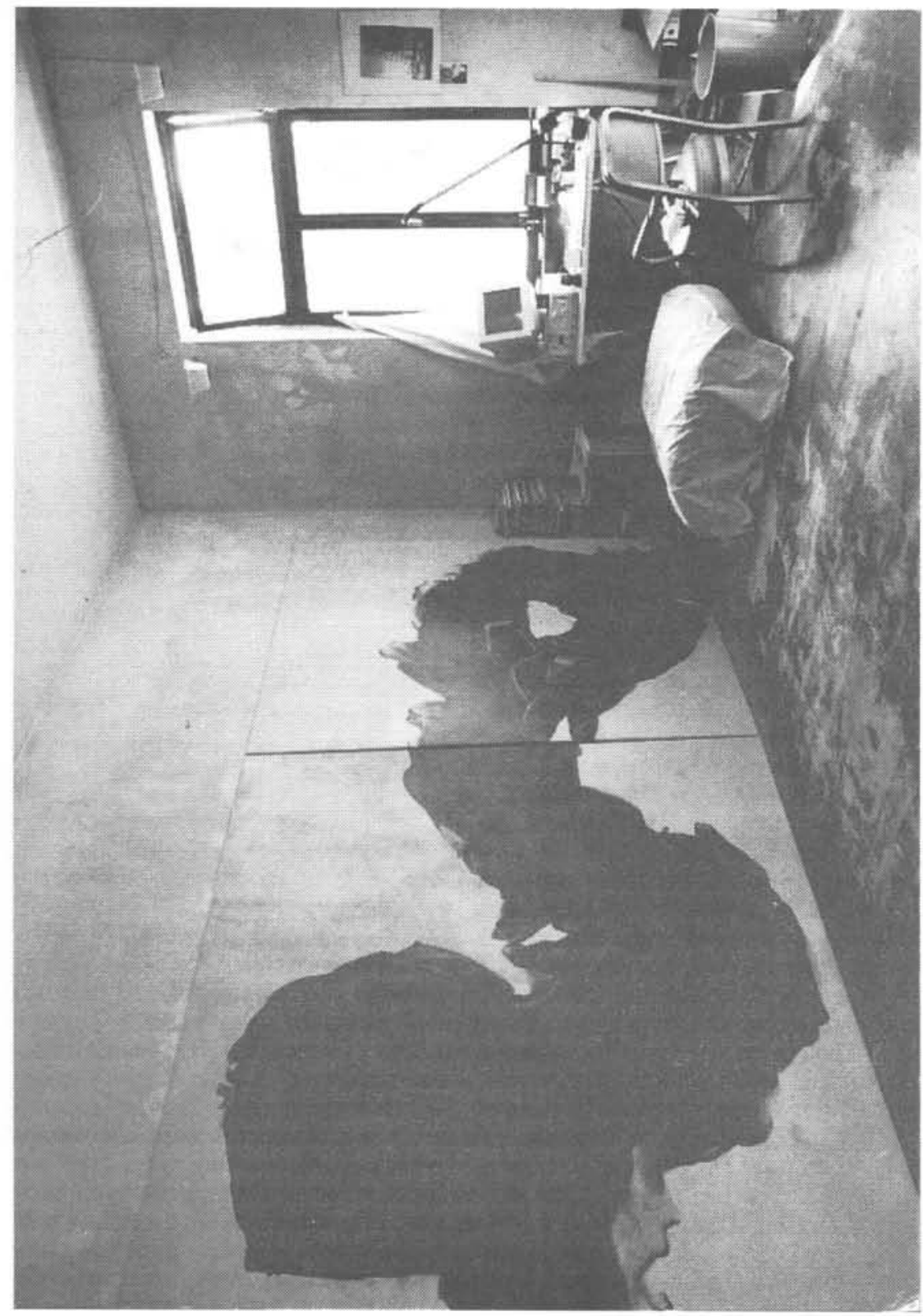

Joanna Jones, Malerei von Ort

Haus am Lûtzowplatz

Fördererkreis Kulturzentrum Berlin 